BOLETÍN DEL MUSEO CHILENO DE ARTE PRECOLOMBINO

Vol. 16, No 1, 201 1, pp. 105-1 18, Santiago de Chile ISSN 0716-1530

\title{
MOCHE SUBSTYLES: KEYS TO UNDERSTANDING MOCHE POLITICAL ORGANIZATION
}

\author{
SUBESTILOS MOCHE: CLAVES PARA LA COMPRENSIÓN \\ DE LA ORGANIZACIÓN POLÍTICA MOCHE
}

\section{Christopher B. DONNAN*}

Variations in Moche fine ware ceramics have generally been attributed to stylistic evolution through time. This article proposes an alternative explanation for stylistic variation-that different polities within the Moche territory were deliberately producing their own distinct variants, or substyles, of fine ware ceramics as a means of expressing their identity. Each substyle had its own center of production and its own beginning, fluorescence, and decline. The chronology of the substyles was not sequential, with one beginning when the previous one ended. Instead, the story was much more complex, with substyles frequently overlapping in time. The recognition of distinct Moche substyles can provide important insights into Moche civilization. To the extent that substyles are defined and their production identified both geographically and temporally, it will be possible to identify distinct Moche polities and to assess their relative strength as they developed and declined.

Key words: Moche, ceramic styles, north coast of Peru, chronology

Las variantes en la cerámica fina Moche han sido generalmente atribuidas a la evolución estilística a través del tiempo. Este artículo propone una explicación alternativa: que diferentes entidades políticas dentro del territorio Moche produjeron deliberadamente sus propias variantes o subestilos de cerámica fina, como una manera de expresar su identidad. Cada subestilo tuvo su propio centro de producción, así como su propio inicio, florecimiento y declive. La cronología de los subestilos no fue secuencial, con uno comenzando cuando otro terminaba. En cambio, hubo una historia mucho más compleja, con subestilos frecuentemente traslapados en el tiempo. El reconocimiento de distintos subestilos Moche puede proveer importantes aproximaciones a la civilización Moche. En la medida de que los subestilos estén definidos y su producción identificada geográfica y temporalmente, será posible identificar a las entidades politicas y evaluar su relativa fortaleza durante su desarrollo y declive.

Palabras clave: Moche, estilos de cerámica, costa norte del Perú, cronología
In 1948 Larco Hoyle published his five-phase chronology of Moche ceramics-a chronology that seemed to fit all of the archaeological evidence available at that time. Although Larco's chronology did not deal with changes in plain domestic ceramics, it provided a valuable means of recognizing sequential stages in the development of Moche fine ware ceramics. It became widely accepted and almost universally used until the 1990's, when it was realized that the Larco chronology was only valid for the Southern Moche Region, and a second linear chronology was proposed for the Northern Moche Region that consists of Early, Middle, and Late phases (Castillo \& Donnan 1994; Castillo 2001). ${ }^{1}$

In this article, I propose that the distinct variations in Moche fine ware ceramics are not necessarily due to stylistic evolution through time, but are sometimes the result of different polities deliberately producing their own distinct variants, or substyles, of ceramics as a means of expressing their identity. To elucidate the concept of substyles, this article focuses on the fine ware ceramics produced by four different Moche polities.

\section{MORO SUBSTYIE}

The site of San José de Moro, located in the lower part of the Jequetepeque Valley (fig. 1), produced a distinctive assemblage of fineline painted ceramics between approximately AD 650 and 800 (Castillo 2001; McClelland

* Christopher B. Donnan, Department of Anthropology, University of California, Los Angeles, CA (UCLA) 90095-1553, USA, email: cdonnan@anthro.ucla.edu Recibido: febrero de 2011. Aceptado: julio de 2011. 


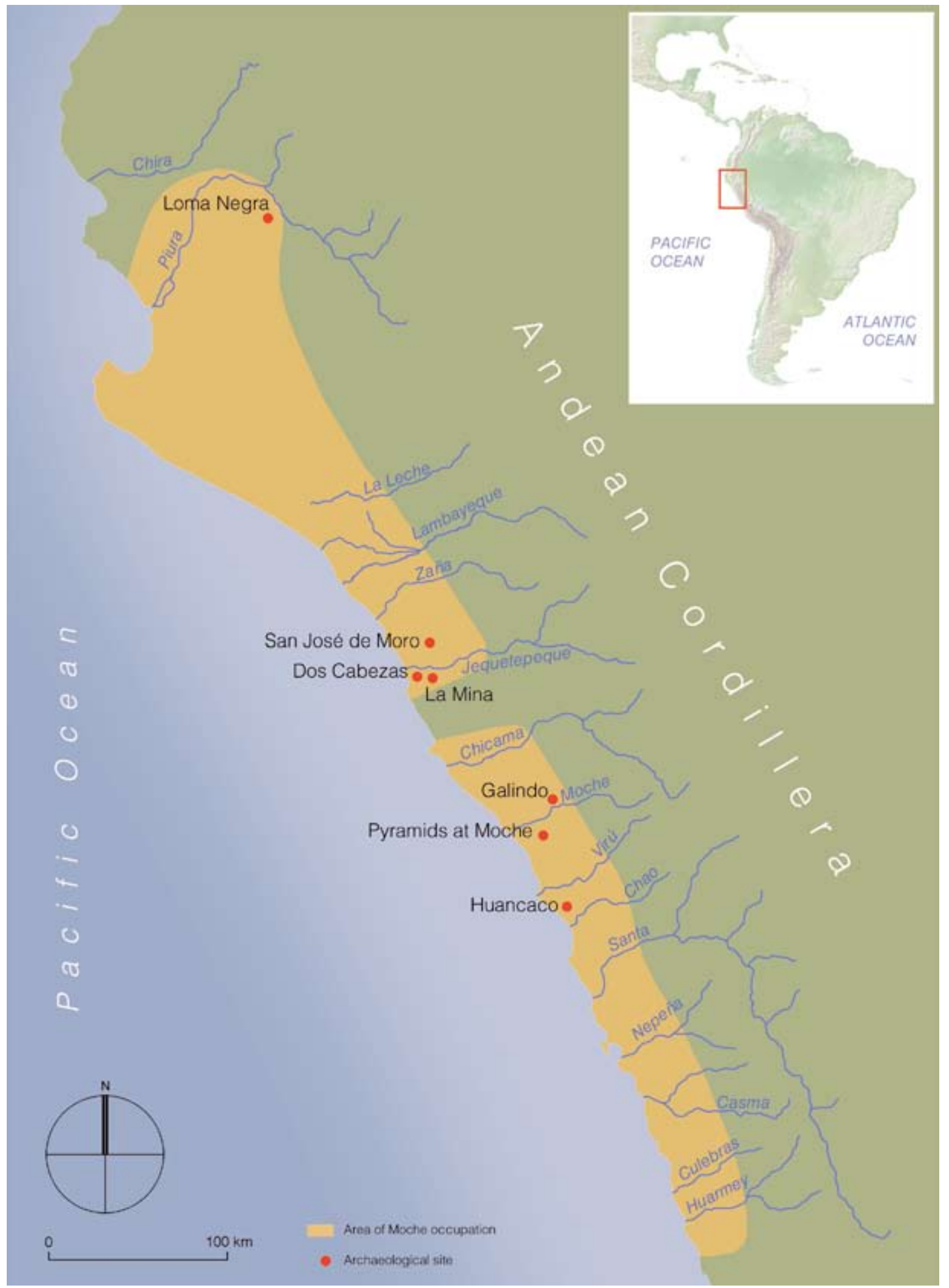

Figure 1. Map of the north coast of Peru. Figura 1. Mapa de la costa norte de Perú. 
et al. 2007). The fineline painted vessels are usually stirrup spout bottles (figs. 2a-f), almost all of which have chambers with ring bases-a feature seldom found on Moche stirrup spout bottles from other regions. Moreover, the spouts of stirrup spout bottles from Moro have two features that are not found elsewhere: fineline paintings of weapon bundles (figs. 2a-d, f), and modeled plants, animals, and human figures (figs. $2 \mathrm{~d}$, e).

San José de Moro ceramics also have features that were borrowed from the Wari ceramic tradition. These include vessel forms such as double spout and bridge bottles (fig. 2g), pod-shaped vessels (fig. 2h), and cups (fig. 2i); certain Wari design motifs (fig. 2h, i), and polychrome slip painting (figs. 2f-i). Moro potters combined these Wari features with traditional Moche vessel forms, design motifs, and painting techniques to create a distinctive and easily recognizable substyle of Moche ceramics.

Another striking characteristic of the Moro substyle is the deliberate use of distortion and abstraction in the depiction of fineline painted figures. Late Moche fineline paintings produced in other areas portray figures with remarkable anatomical accuracy (fig. 3). Most of the figures painted at San José de Moro, however, have misshapen mouths and faces, often with long noses that are awkwardly appended to foreheads (figs. 4a-d). The arms and legs often appear to have an extra elbow or knee, and the bodies of many seated figures are replaced by a dome shape (fig. 4c), which would be unrecognizable without seeing more naturalistic representations of seated figures. The depictions of animals and supernatural creatures by Moro painters are also abstract and distorted.

One might suggest that the Moro painters were simply not as skilled as painters working in other areas, and thus were unable to achieve the same degree of anatomical accuracy. Yet Moro painters produced many fineline paintings of remarkable quality. The vessel shown in figure $4 \mathrm{e}$, for example, has extraordinarily complex painting that is masterfully rendered over its entire surface. But the figures in this painting exhibit the same degree of distortion as that of other Moro paintings. The kneeling figure in the lower register has an oversized torso swept into a large curve that ends in the sleeve of his shirt, and both he and the figures in front of and above him have arms bent at strange angles. Another example of deliberate abstraction and distortion is figure $4 \mathrm{~d}$, in which each figure grasps a tumi knife in one very recognizable hand, while their other hand is weirdly distorted. The amount of distortion and abstraction suggests that Moro potters were aware of the uniqueness of their painting, and were intentionally using it to make their ceramics distinctive.

The combination of distinctive features of Moro ceramics make it a substyle that would have been easy to recognize-not only by Moro people, but also by people in other regions. It would have symbolized the ethnicity of the Moro polity.

\section{DOS CABEZAS SUBSTYLE}

The Dos Cabezas substyle of Moche ceramics was produced between approximately AD 300 and 600 at the site of Dos Cabezas, located at the delta of the Jequetepeque River (fig. 1). It is strikingly distinct from the Moro substyle in including neither fineline painting nor polychrome slip painting. Instead, it is characterized by a remarkably sophisticated use of three dimensional and low relief sculpture to depict a wide range of subject matter with amazing realism (fig. 5). The ceramics were not mold made-each piece was individually modeled by a highly skilled potter. Yet the potters portrayed each subject in a remarkably standardized manner. Warriors, for example, consistently kneel on one knee, hold a club in one hand and a shield in the other, and look directly forward in a static posture (fig. 5a). Each wears body armor, a pelt-like object on his back, and a helmet with a crescent-shaped headdress ornament flanked by stepped elements.

Felines were frequently portrayed by Dos Cabezas potters, but in only four rigidly prescribed ways: in combat with a large snake (fig. 5b), lying on their side with their front paws down (fig. 5c), sitting on their haunches with their front paws down (fig. 5d), or sitting on their haunches with their front paws raised (fig. 5e). When portraying felines in one of these four standardized postures, the potters also conformed to other rules. They consistently depicted the pads and wrinkles of the feline's feet. They always showed the head looking directly forward with the ears up, the whiskers clearly indicated with either incision or slip paint, and the mouth open with the tongue extending beyond the fangs. They never turned the head to one side, closed the mouth, or showed the ears pointing back. The feline heads, although modeled by various potters, are so similar in size and detail that they are nearly interchangeable from one ceramic vessel to another.

Various seated figures were also portrayed repeatedly in the Dos Cabezas substyle of Moche ceramics, again with remarkable consistency. One figure carries a jar on his shoulder and invariably is shown wearing a hat 


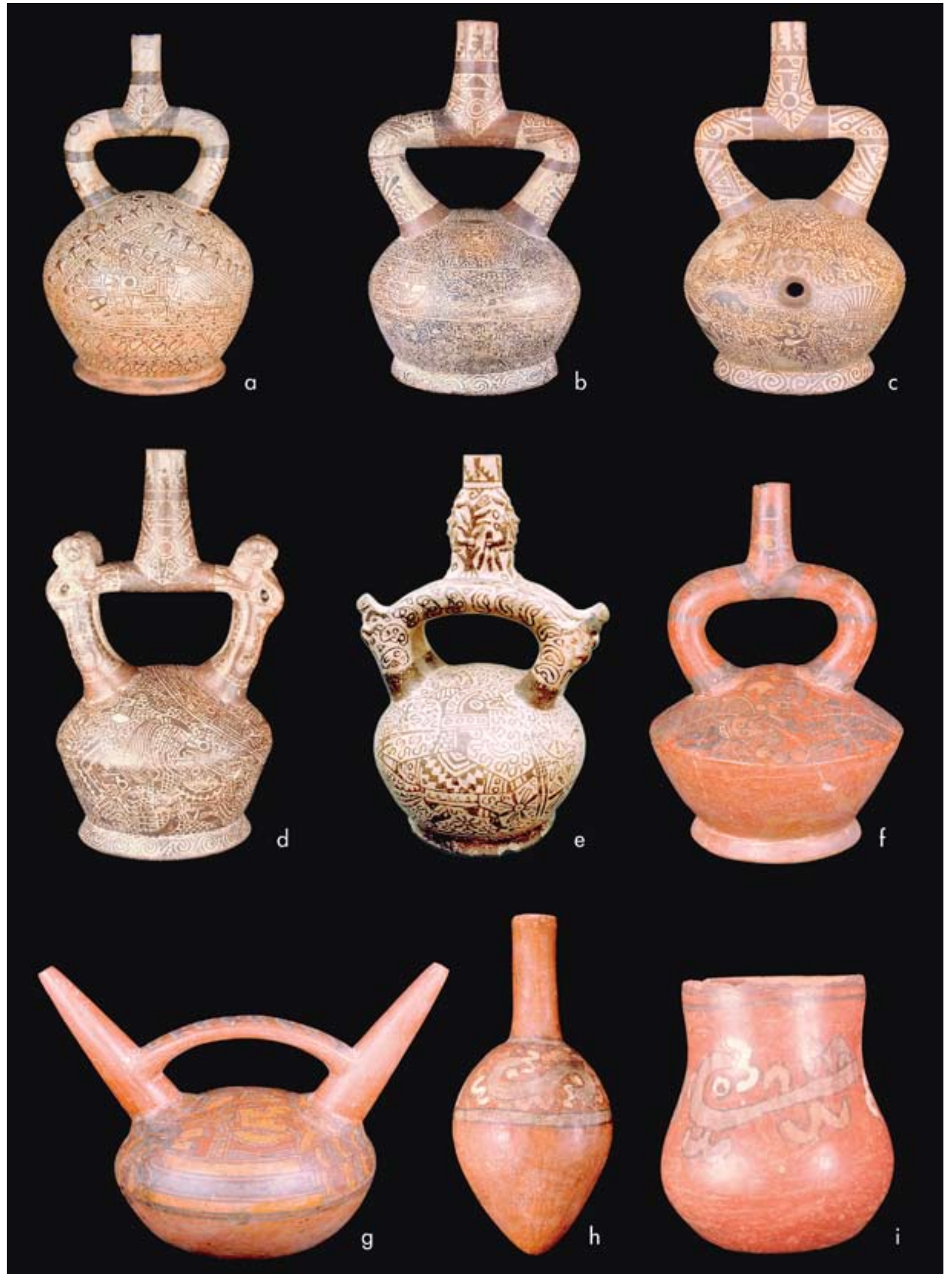

Figure 2. Ceramic vessels of the San José de Moro substyle. Figura 2. Vasijas cerámicas del subestilo San José de Moro. 

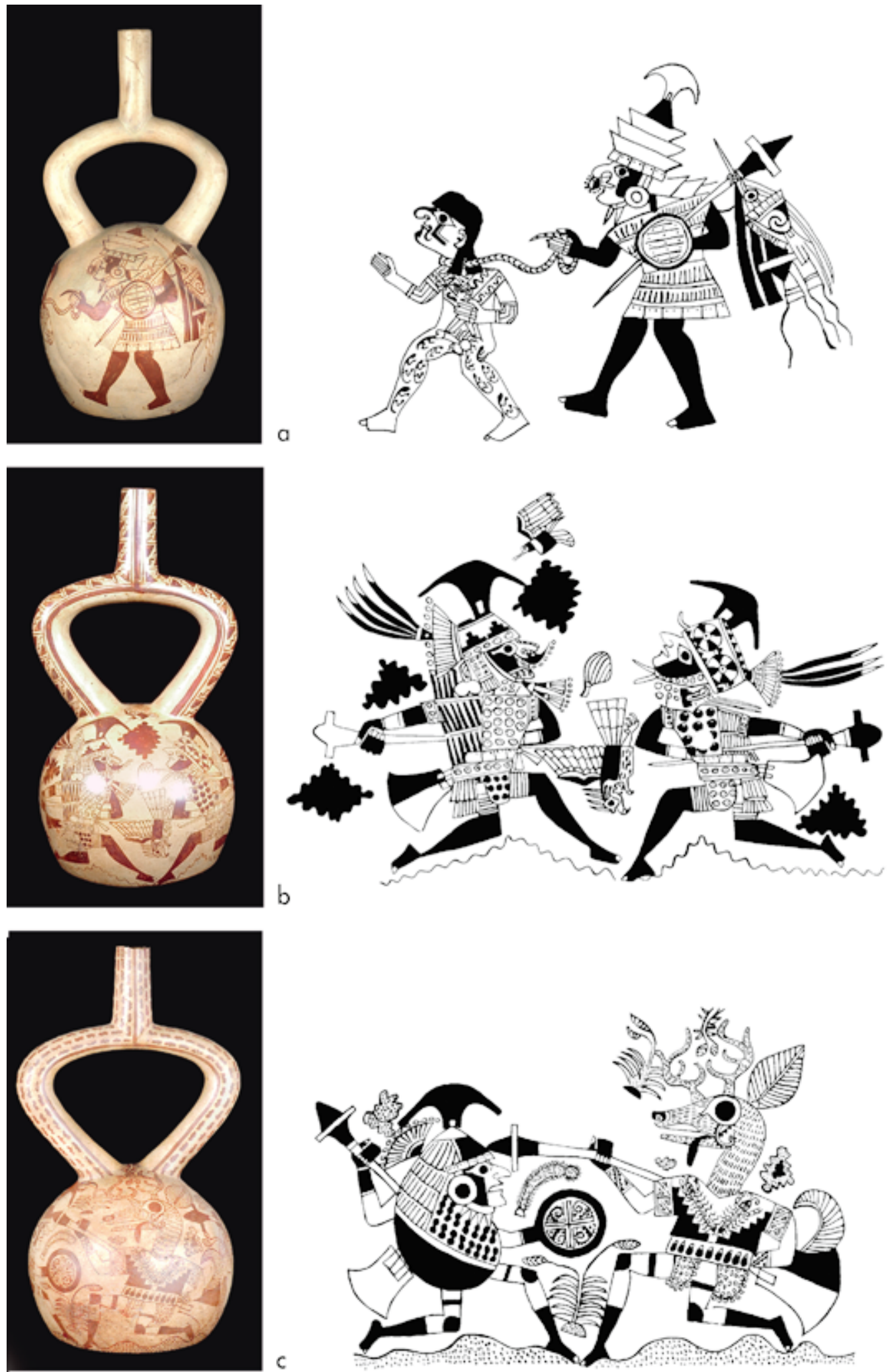

Figure 3. Fineline painted vessels from the Southern Moche Region.

Figura 3. Vasijas pintadas en linea fina, del territorio austral de los Moche. 

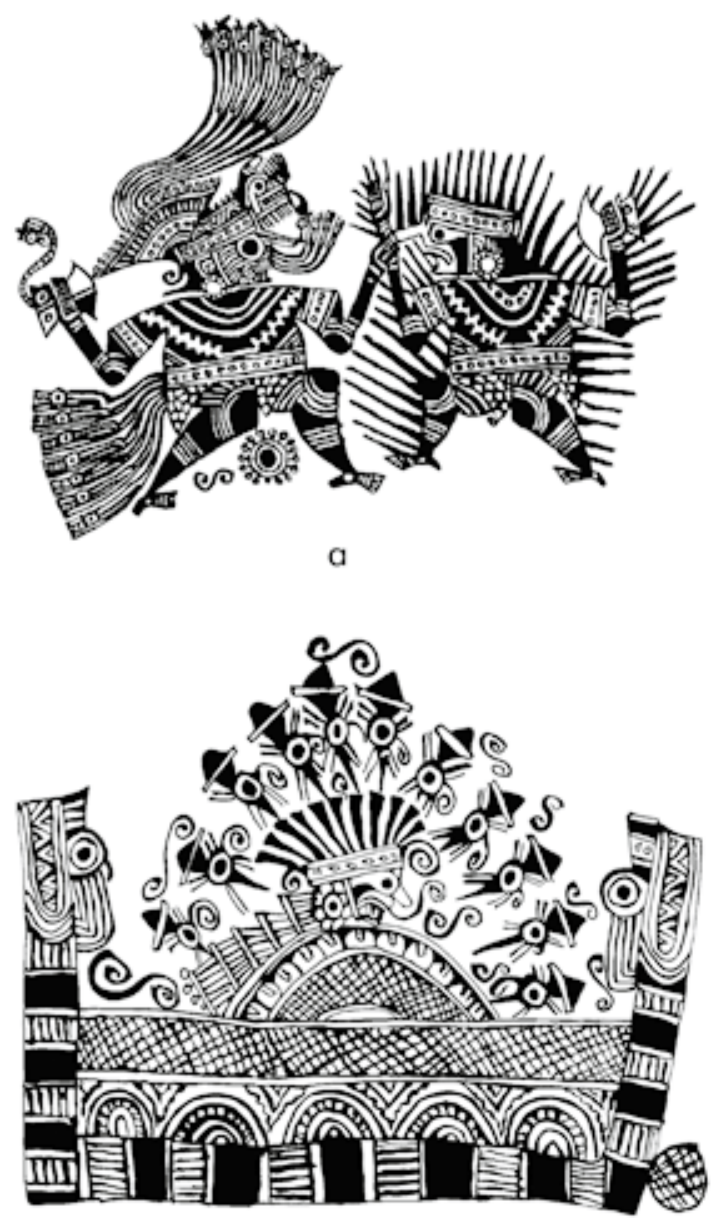

C
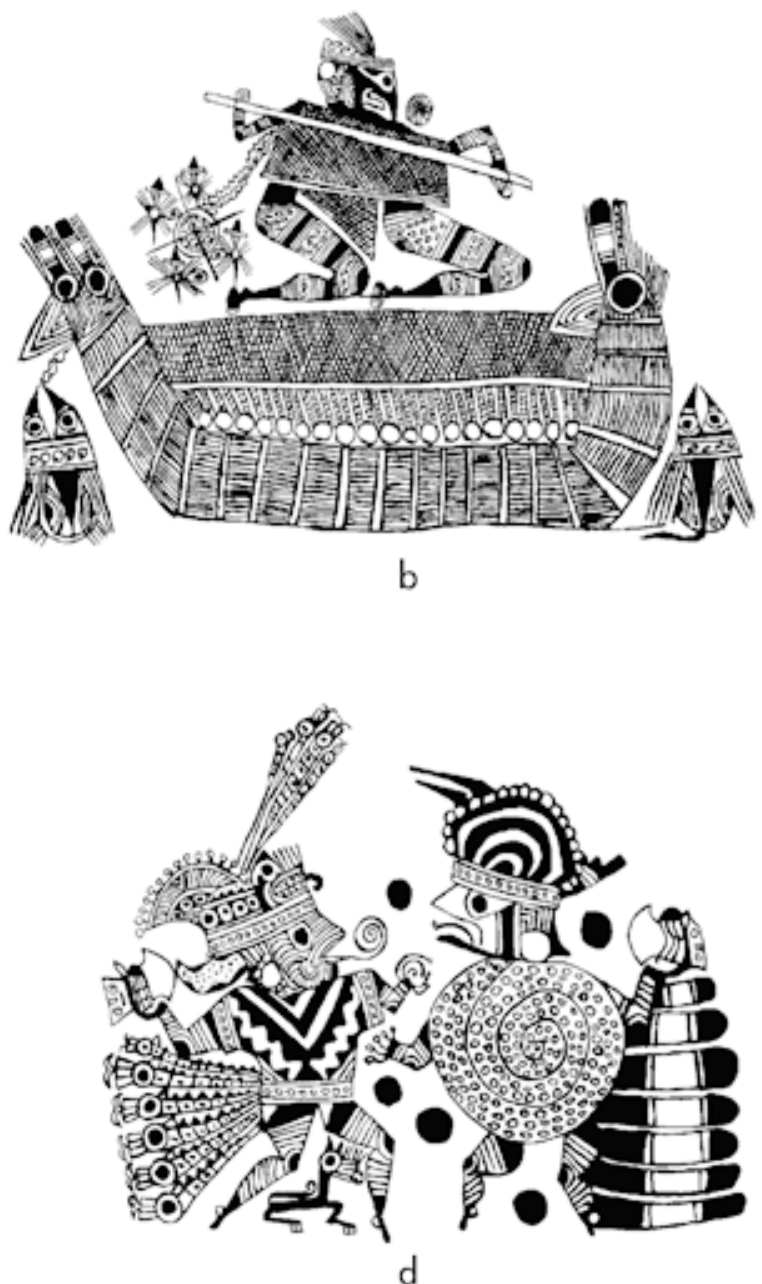
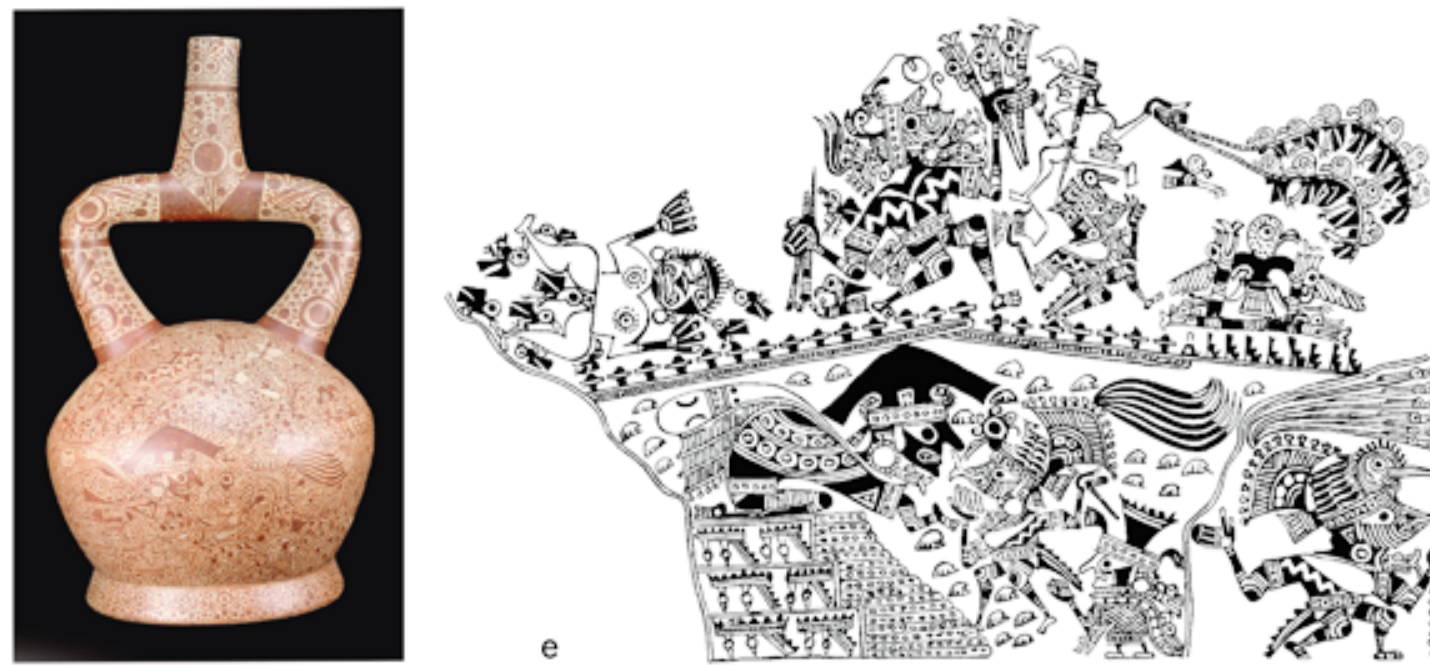

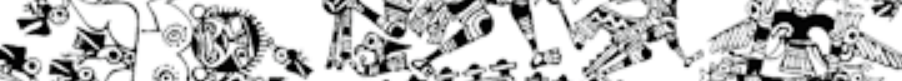

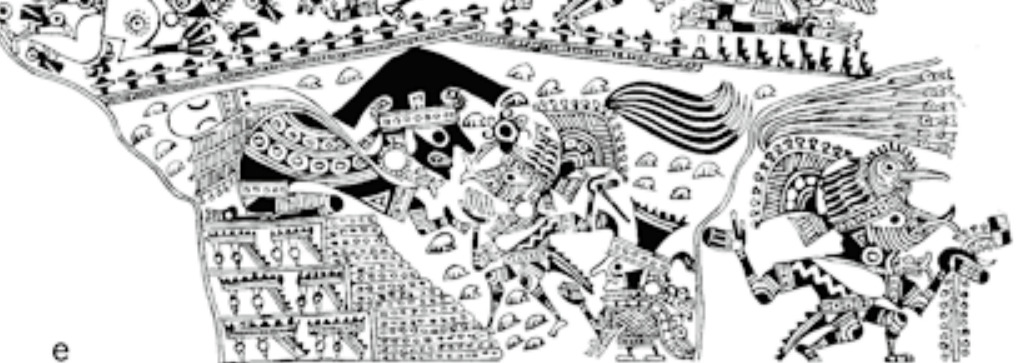

Figure 4. Fineline painted vessels of the San José de Moro substyle.

Figura 4. Vasijas pintadas en línea fina, del subestilo San José de Moro. 

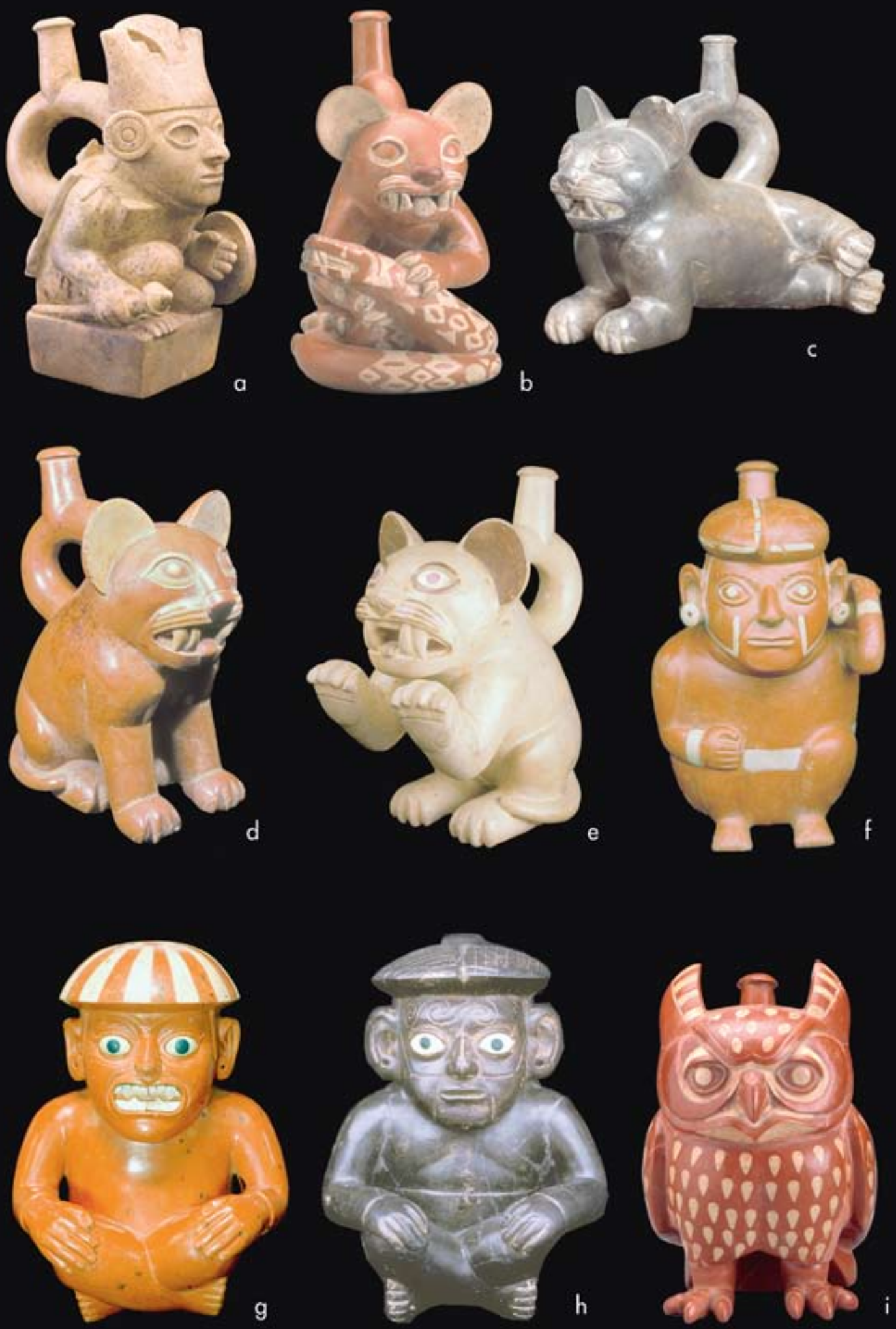

Figure 5. Ceramic vessels of the Dos Cabezas substyle. Figura 5. Vasijas cerámicas del subestilo Dos Cabezas. 
that is divided by a crease from front to back, with one half slightly larger and higher than the other (fig. $5 \mathrm{f}$ ). Another seated figure has both hands on his knees, and consistently wears a dome-shaped hat with stripes radiating out from the center (fig. $5 \mathrm{~g}$ ). Yet another figure is always portrayed wearing a hat divided in half from front to back, with stripes extending to the side on one side and forward on the other side (fig. 5h), and always with the same scroll pattern across his forehead. Like the Dos Cabezas warriors and felines, seated figures clearly conformed to specific guidelines. The same rigidity is seen in the way the potters consistently portrayed owls (fig. 5i), parrots, condors, and a wide range of supernatural figures (Donnan 2003, 2007).

At La Mina, a site located a few kilometers east of Dos Cabezas, a salvage excavation of what remained of a looted tomb recovered a wonderful set of Dos Cabezas substyle ceramics (Narváez 1994). As shown in figure 6, these included, in the front row, a kneeling warrior (the crescent portion of his headdress was broken but lying in place behind his head), a jar carrier, and a reclining feline (with only the ears and spout showing). In the back row were the figure with the scroll pattern across his forehead, an owl, and the figure wearing a domeshaped hat with stripes radiating out from the center. Each of these ceramic vessels can be clearly attributed to the Dos Cabezas substyle.

The consistencies of the Dos Cabezas substyle indicate that the potters were working under rigid guidelines to produce ceramics that were distinctive and recognizably different from those produced elsewhere. This substyle of Moche ceramics would have been symbolic of the Dos Cabezas polity.

\section{HUANCACO SUBSTYLE}

Another very distinct substyle of Moche ceramics has recently been reported from the site of Huancaco, a site that for many years was considered one of the most important Moche sites in the Viru Valley (fig. 1). The adobe types, architectural forms, polychrome wall paintings, and even some of the metal objects from Huancaco are clearly Moche style, and the dates for the construction and occupation of Huancaco (approximately AD 550-680) fit well within the span of Moche civilization (Bourget 2003, 2010). Yet the ceramics excavated at Huancaco are so distinctive from those generally thought to be Moche style that Bourget has suggested that they are not Moche at all (Bourget 2003, 2010). How then, is it possible to account for them? I suggest that they were produced by potters at Huancaco who were deliberately creating a distinctive and easily recognizable Moche substyle that would symbolize their polity.

Although a few of the ceramics excavated at Huancaco are typically Gallinazo (Viru) or Recuay style, nearly all others appear to be Moche style. This is particularly the case with the modeled human forms, which have clear Moche characteristics (figs. $7 \mathrm{a}-\mathrm{c}$ ). It is also the case with the stirrup spout bottles, although some of the chambers are unusual. One tall cylindrical vessel is decorated with an incised geometric pattern (fig. 7d), while two others have an unusual red on orange design (figs. 7e, f). Nevertheless, all of the spout fragments from stirrup spout bottles are well within the range of Moche spout forms (e.g., fig. 7g). Ceramics from Huancaco also include dippers (figs. 7h, i)-vessels that are typical of Moche ceramics, and flaring bowls (figs. 8a-e)-vessels that are found only in the Moche ceramic style. Like Moche ceramics, most of the ceramics from Huancaco are decorated with red and white slip, and are painted with typical Moche design motifs.

Admittedly, some features of the ceramics from Huancaco seem foreign to what is generally thought of as Moche style. The rounded open plates (figs. 8f, g) are a vessel form that is not recognized as Moche. Yet the examples from Huancaco are consistently painted with typical Moche design motifs, using typical Moche red and white slip.

Perhaps the most unusual feature of Huancaco ceramics is the use of polychrome post-fired pigment (figs. 8h, i). This colorful decoration seems strikingly foreign to what is considered Moche. Yet, as noted above, the Moro substyle includes vessel forms (double spout and bridge bottles, pod-shaped vessels, and cups) as well as polychrome slip painting, both of which seem to be outside of the Moche ceramic tradition. Therefore, the unusual vessel forms and polychrome paint of the Huancaco substyle should not be seen as evidence that it is a non-Moche style.

I suggest that the ceramics excavated by Bourget at Huancaco are a distinctive substyle of Moche ceramics -one that was made to be deliberately different from ceramics produced elsewhere in order to symbolize the polity of Huancaco.

Viewing the fine ware ceramics from Moro, Dos Cabezas, and Huancaco as distinct substyles of Moche ceramics, provides an interesting alternative to the linear chronologies of distinct phases that have been proposed. Although stratigraphic excavations support the general chronological sequence of Larco's five phase chronology, recent research indicates that his phases at least partially overlap in time. For example, it had been thought that the Phase IV occupation at Huacas de 


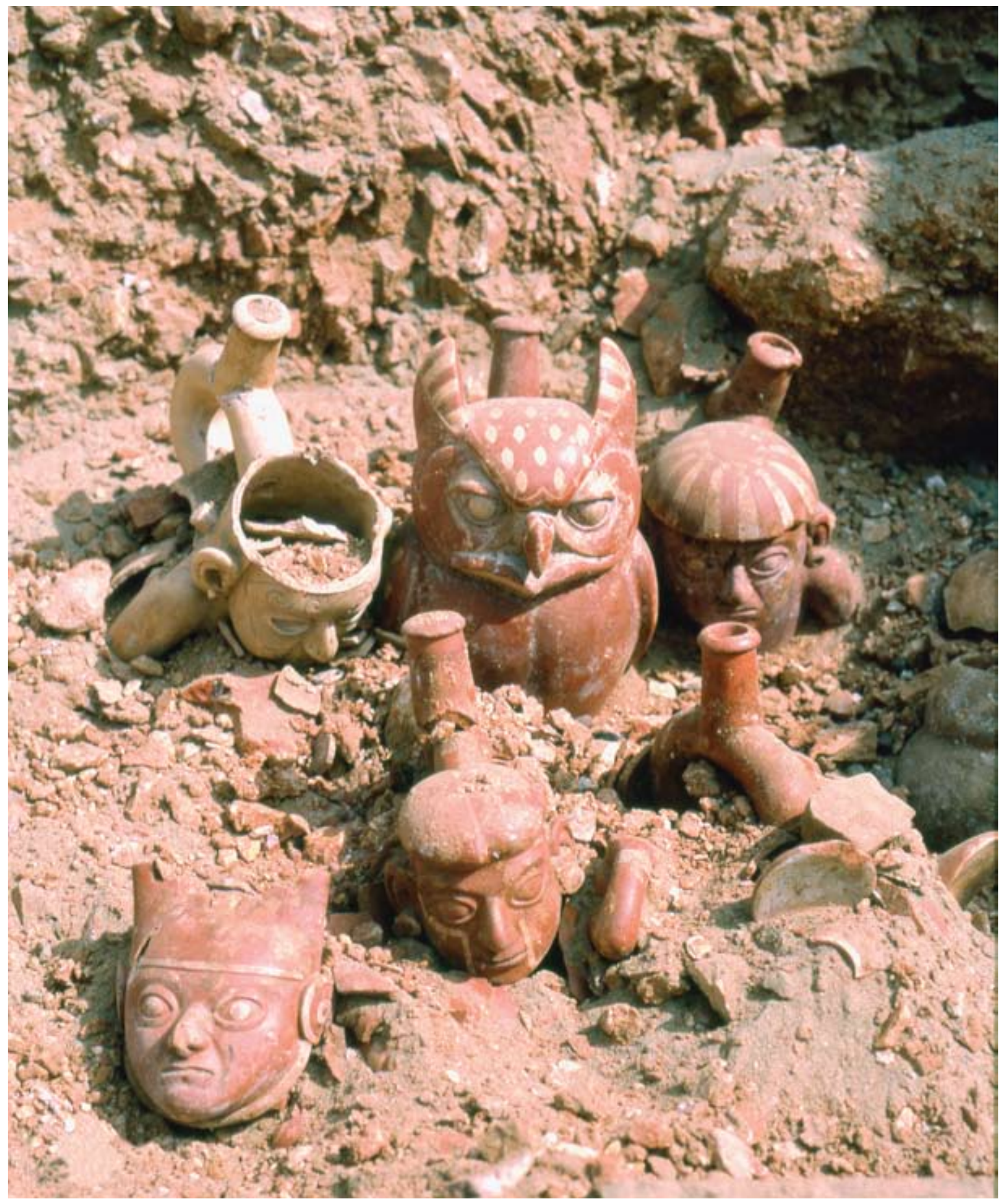

Figure 6. Dos Cabezas substyle vessels in situ at La Mina.

Figura 6. Vasijas del subestilo Dos Cabezas in situ en La Mina. 


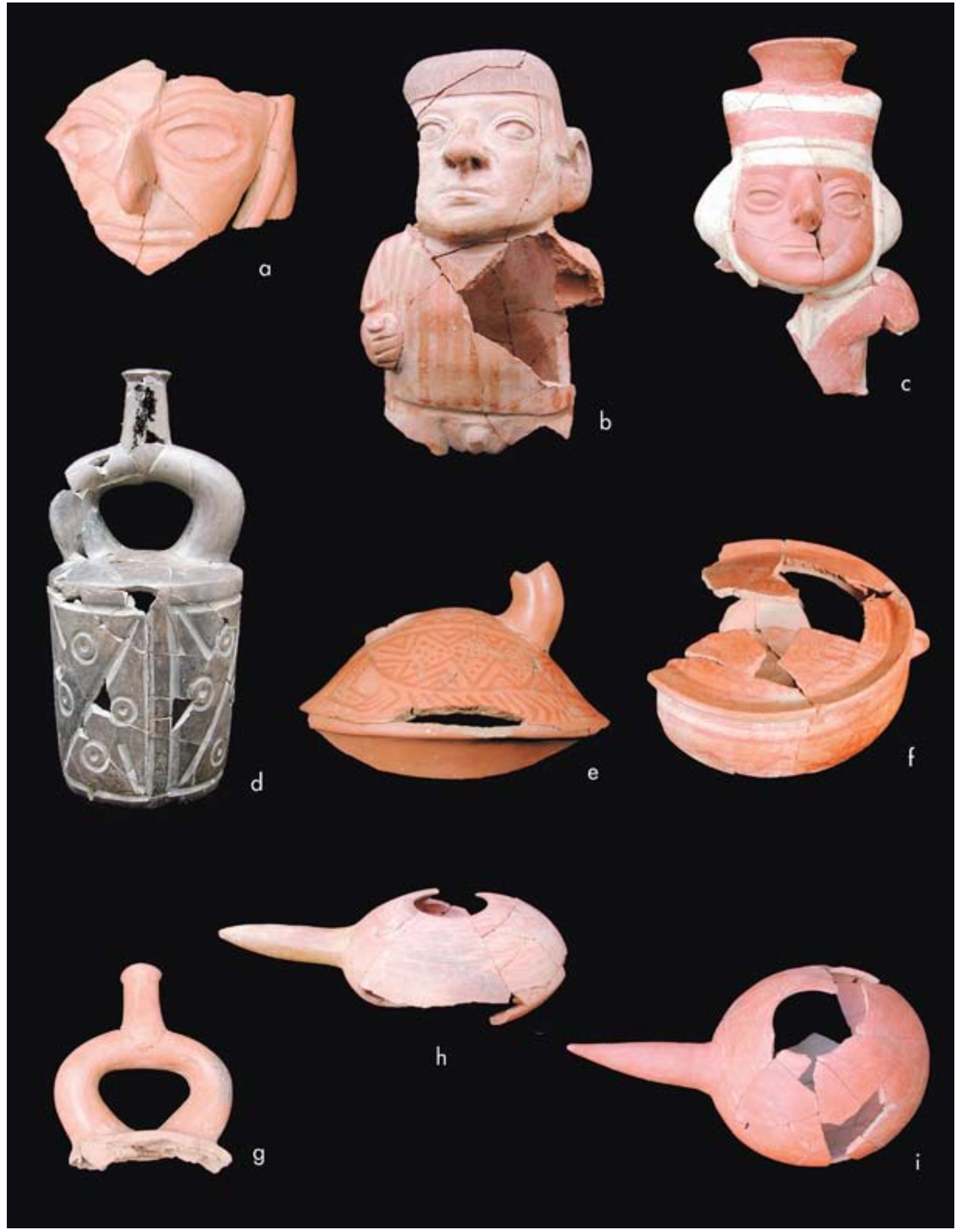

Figure 7. Ceramic vessels of the Huancaco substyle. Figura 7. Vasijas cerámicas del subestilo Huancaco. 


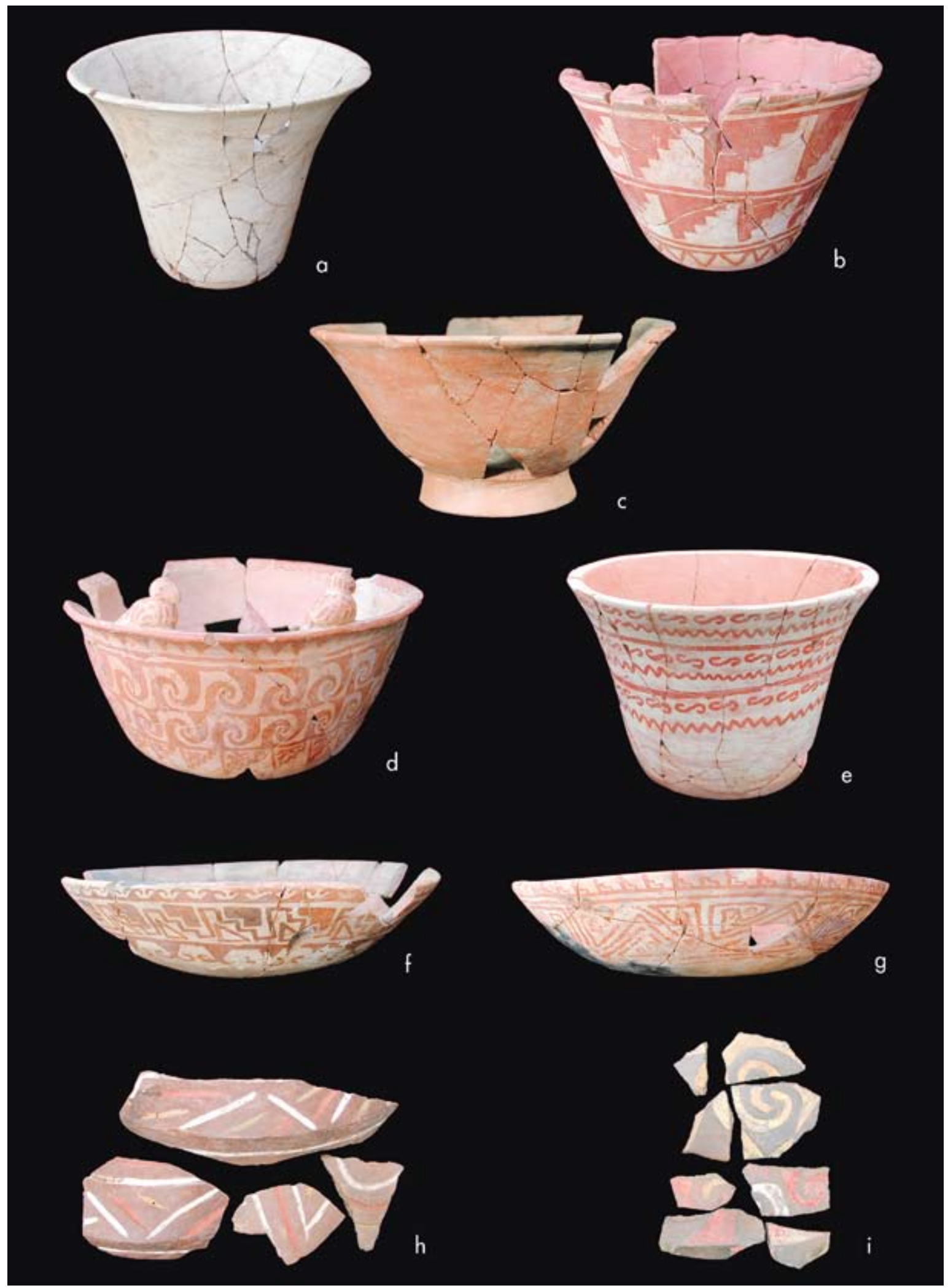

Figure 8. Ceramic vessels of the Huancaco substyle. Figura 8. Vasijas cerámicas del subestilo Huancaco. 

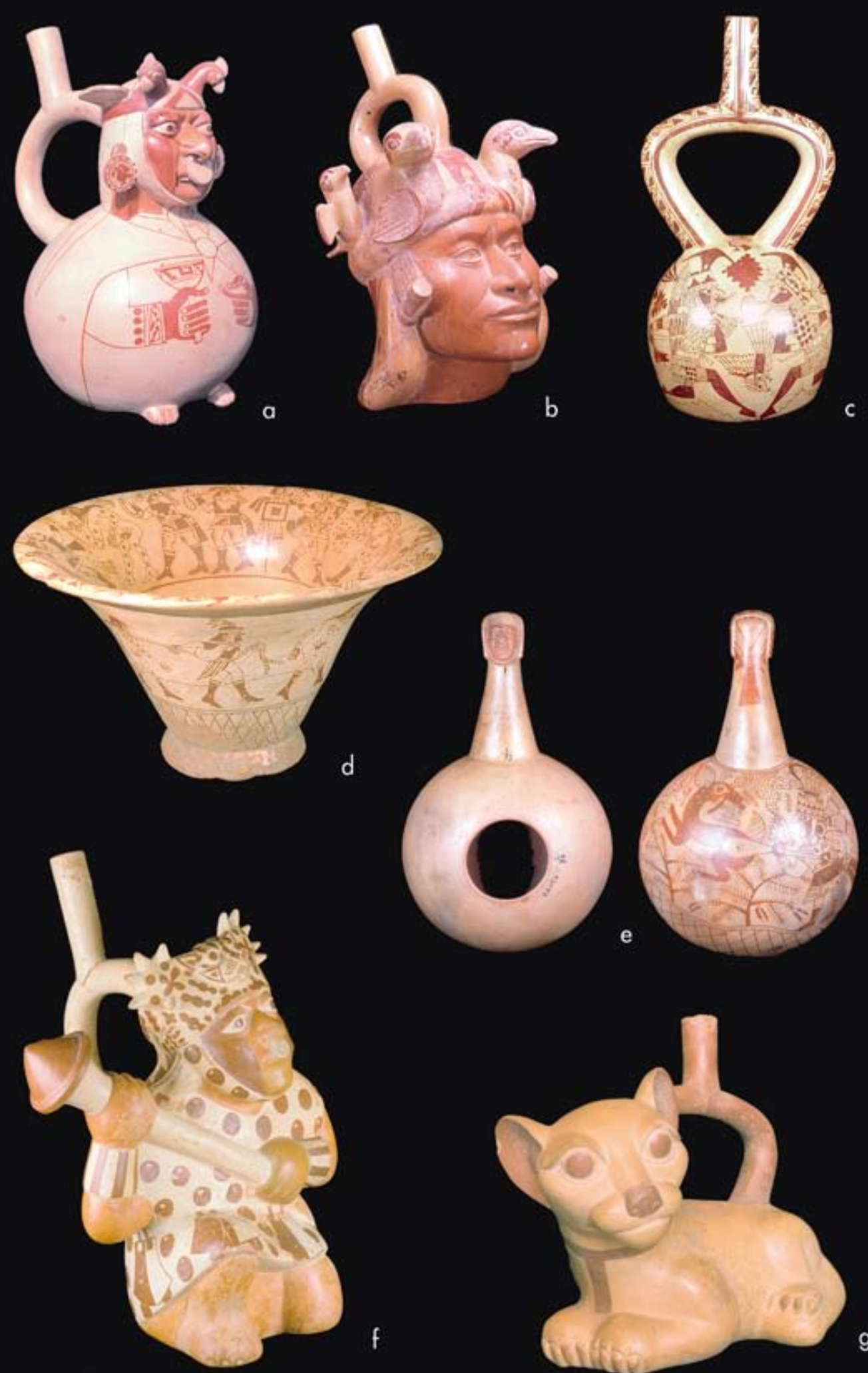

Figure 9. Ceramic vessels of the Huacas de Moche substyle. Figura 9. Vasijas cerámicas del subestilo Huacas de Moche. 
Moche ended when the Phase V occupation at Galindo began. Radiocarbon dates now indicate that the Phase IV occupation at Huacas de Moche continued for more than a century after the beginning of Phase $\mathrm{V}$; and thus Larco's Phases IV and V were, at least in part, contemporary (Lockard 2008: 279-281).

If, instead of thinking of Larco's phases as chronologically sequenced time periods, they are seen as substyles of Moche ceramics, the partial contemporaniety of Phases IV and V is not a problem. What Larco defined as Phase IV may simply be a substyle of Moche ceramics that was deliberately produced by the polity at the Huacas de Moche to express its identity. It could be called the Huacas de Moche substyle.

\section{HUACAS DE MOCHE SUBSTYLE}

The Huacas de Moche substyle (fig. 9) would include ceramics that have been widely identified as Phase IV: those with Phase IV stirrup spouts and fineline painting (Donnan \& McClelland 1999), typical Phase IV flaring bowls and dippers, and most of the highly realistic portrait head vessels (Donnan 2004). Thus it would include a wide range of features that have long been recognized as characteristic of Phase IV. I suggest that these features were being adhered to by the potters at the Huacas de Moche to deliberately produce a substyle of Moche ceramics that would symbolize the polity at that site.

The geographical distribution of the Huacas de Moche substyle over nearly all Moche sites in the Chicama, Viru, Chao, and Santa valleys suggests that the people who originated this substyle gained political dominance over this large region, becoming the largest political entity ever developed within the Moche realm.

It is interesting to consider how different the Huacas de Moche substyle is from the Moro substyle, the Dos Cabezas substyle, and the Huancaco substyle. Note, for example, the difference between the way warriors and felines are depicted in the Huacas de Moche substyle (figs. 9f, g) and the Dos Cabezas substyle (figs. 5a, b-e). I am confident that the Moche people would have easily recognized the differences, and been able to identify the source of each of these substyles and the polity it represented.

If Larco's Phase IV was a Moche substyle rather than a chronological period, his other phases could also be substyles. Larco's Phase III, for example, may have been a somewhat earlier substyle, developed by another polity to express its identity.
Each distinct substyle of Moche fine ware ceramics would have had its own center of production. Also, each would have had its own beginning, fluorescence, and demise. Ultimately, it should be possible to determine how the substyles related to one another chronologically, but instead of the chronology being sequential-one beginning when the previous one ended-we would expect a much more complex picture, with substyles frequently overlapping in time.

The recognition of distinct Moche substyles can provide important insights into Moche civilization. To the extent that substyles can be defined and their production identified both geographically and temporally, it will be possible to identify distinct Moche polities and assess their relative strength as they developed and declined. Furthermore, to the extent that ceramics of one substyle are found in the areas of other substyles, it will be possible to assess the degree to which distinct Moche polities were interacting. The key to these assessments, of course, is having a detailed description of each substyle so that its characteristic features are known and can be clearly recognized.

It is hoped that by providing the concept of substyles, this paper will generate interest in exploring this aspect of Moche civilization as more evidence becomes available.

ACKNOWLEDGEMENTS I am very grateful to Steve Bourget for allowing me to publish his illustrations of ceramics from Huancaco, and for our lively discussions about whether or not the people of Huancaco were Moche.

\section{NOTE}

${ }^{1}$ A very insightful comment about the limitations of Moche chronological phases based on the sequential evolution of ceramics was published by Uceda and Mujica in 2003 (346-347). As they stated "[...] lo que es obvio es que si bien la secuencia estilística de Larco nos permite una forma de ordenamiento cronológico relativa, no nos permite ver con meridiana claridad los procesos históricos. Debemos fomentar investigaciones encaminadas a concatenar ambas líneas de trabajo".

\section{REFERENCES}

Bourget, S., 2003. Somos diferentes: Dinámica ocupacional del sitio Castillo de Huancaco, valle de Virú. In Moche: Hacia el final del milenio. Actas del segundo coloquio sobre la cultura Moche, S. Uceda \& E. Mujica, Eds., pp. 245-267. Trujillo / Lima: Universidad Nacional de Trujillo / Pontificia Universidad Católica del Perú.

- 2010. Cultural Assignations during the Early Intermediate Period: The Huancaco Case. In New Perspectives on Moche Political Organization, J. Quilter \& L. J. Castillo, Eds., pp. 201-222. Washington, D. C: Center for pre-Columbian Studies, Dumbarton Oaks. 
Castillo, L. J., 2001. The Last of the Mochicas: A View from the Jequetepeque Valley. In Moche Art and Archaeology in Ancient Peru, Studies in the History of Art 63. Center for Advanced Studies in the Visual Arts, Symposium Papers XL, J. Pillsbury, Ed., pp. 307-332. Washington, D. C.: National Gallery of Art.

Castillo, L. J. \& C. B. Donnan, 1994. Los mochicas del norte y los mochicas del sur. In Vicús, K. Makowski, Comp., pp. 143-181. Lima: Banco de Crédito del Perú.

Donnan, C. B., 2003. Tumbas con entierros en miniatura: Un nuevo tipo funerario Moche. In Moche: Hacia el final del milenio. Actas del segundo coloquio sobre la cultura Moche, S. Uceda \& E. Mujica, Eds., pp. 43-78. Trujillo / Lima: Universidad Nacional de Trujillo / Pontificia Universidad Católica del Perú.

2004. Moche Portraits from Ancient Peru. Austin: University of Texas Press.

2007. Moche Tombs at Dos Cabezas. Los Angeles: Cotsen Institute of Archaeology, University of California.

Donnan, C. B. \& D. McClelland, 1999. Moche Fineline Painting. Its Evolution and Its Artists. Los Angeles: Fowler Museum of Cultural History, University of California.
Larco Hoyle, R., 1948. Cronología arqueológica del norte del Perú. Buenos Aires: Sociedad Geográfica Americana.

LOCKARD, G., 2008. A New View of Galindo: Results of the Galindo Archaeological Project. In Arqueología mochica: Nuevos enfoques, L. J. Castillo, et al., Eds., pp. 275-294. Lima: Fondo Editorial de la Pontificia Universidad Católica del Perú e Instituto Francés de Estudios Andinos.

McClelland, D.; D. McClelland \& C. B. Donnan, 2007. Moche Fineline Painting from San Jose de Moro. Los Angeles: Cotsen Institute of Archaeology at UCLA, University of California.

Narváez, A., 1994. La Mina: una tumba Moche I en el valle de Jequetepeque. In Moche: propuestas y perspectivas : Actas del primer coloquio sobre la cultura Moche, Travaux de l'Institute Français d'Etudes Andines 79, S. Uceda \& E. Mujica, Eds., pp. 59-81. Lima: Institute Français d'Etudes Andines.

UCEDA, S. \& E. MujicA, 2003. Los estudios sobre Moche al inicio del nuevo milenario. In Moche: hacia el final del milenio. Actas del Segundo Coloquio sobre la Cultura Moche, S. Uceda \& E. Mujica, Eds., pp. 337-349. Trujillo/Lima: Universidad Nacional de Trujillo/Pontificia Universidad Católica del Perú. 